\title{
Analisis Kepuasan Pelanggan Produk Kosmetik Emina
}

\author{
Erina Oktaviani ${ }^{1 *}$, Alfatih S Manggabarani $^{2}$, Dewi Cahyani Pangestuti ${ }^{3}$ \\ Universitas Pembangunan Nasional Veteran Jakarta, Indonesia \\ Author E-mail: erinaoktaviani@upnvj.ac.id
}

\begin{abstract}
A B S T R A K
Penelitian ini merupakan penelitian kuantitatif yang dirancang untuk membuktikan dan menganalisis pengaruh harga, citra merek dan kualitas produk terhadap kepuasan pelanggan kosmetik Emina. Populasi dalam penelitian ini adalah pelanggan yang pernah membeli atau sedang menggunakan kosmetik Emina di Kecamatan Bogor Barat Kota Bogor. Besar sampel yang digunakan adalah 100 responden, dan digunakan metode non-probability sampling dengan jenis purposive sampling. Pengumpulan data dilakukan dengan menyebarkan kuesioner melalui formulir google form. Teknik analisis data yang digunakan adalah metode partial least square (PLS). Hasil penelitian ini menunjukkan bahwa variabel harga, citra merek dan kualitas produk berpengaruh signifikan dan signifikan terhadap kepuasan pelanggan.
\end{abstract}

Kata Kunci: Harga, Citra Merek, Kualitas Produk, Kepuasan Pelanggan.

\section{A B S T R A C T}

This research is a quantitative research designed to prove and analyze the effect of price, brand image and product quality on customer satisfaction of Emina cosmetics. The population in this study are customers who have bought or are currently using Emina cosmetics in West Bogor District, Bogor City. The sample size used is 100 respondents, and non-probability sampling method is used with purposive sampling type. Data was collected by distributing questionnaires through a google form. The data analysis technique used is the partial least square (PLS) method. The results of this study indicate that the variables of price, brand image and product quality have a significant and significant effect on customer satisfaction.

Key word: Price, Brand Image, Product Quality, Customer Satisfaction.

Copyright (@ 2021 Authors. This is an open access article distributed under the Creative Commons Attribution License, which permits unrestricted use, distribution, and reproduction in any medium, provided the original work is properly cited. 


\section{PENDAHULUAN}

Kehidupan di masa sekarang memberikan suatu kemudahan serta kepraktisan untuk menjaga penampilan, contohnya penggunaan produk perawatan kecantikan atau kebutuhan primer wanita untuk mempertahankan popularitasnya, karena bagi sebagian wanita, kecantikan merupakan asset suatu keharusan untuk menjaga daya tarik mata. Kosmetik merupakan produk yang unik karena tidak hanya memiliki kemampuan memuaskan kecantikan dasar wanita, tetapi juga menjadi sarana bagi konsumen untuk memperjelas identitas sosialnya saat dilihat masyarakat. Sejalan dengan perkembangan di masa sekarang, kosmetik sudah menjadi kebutuhan utama sebagian wanita. (Patmawati \& Syarif, 2020)

Pada saat ini, persaingan antar bisnis di seluruh dunia semakin tumbuh. Oleh karena itu, perusahaan harus dapat memenuhi kebutuhan konsumen, berusaha menciptakan suatu produk lebih unggul, dan membuat suatu produk yang berbeda dari perusahaan lain. Hal tersebut terlihat pada persaingan perusahaan dengan perusahaan lain dalam menarik konsumen. Industri kecantikan Indonesia menghadirkan peluang yang sangat besar karena pasar Indonesia yang sangat luas. Kementerian Perindustrian dalam (antaranews, 2021) mengatakan, industri kosmetik akan tumbuh signifikan pada 2020. Hal ini terlihat dari kinerja pertumbuhan industri kimia, farmasi dan obat tradisional termasuk kosmetik yang tumbuh 9,39\%.

Berdasarkan pada Gambar 1. rangkuman dari data industry kosmetik di Indonesia pada tahun 2018, terlihat Jawa Barat memiliki angka tertinggi sebesar 112 perusahaan produk kosmetik. Hal ini menunjukkan Jawa Barat merupakan pasar menjanjikan pada berbagai kawasan komersial termasuk produk kosmetik. Pasar kosmetika diwarnai oleh berbagai jenis pemain yaitu produk lokal dan impor. Persaingan pemain lokal yang kompetitif di pasar industry kosmetik di Indonesia saat ini diisi oleh Emina, MakeOver, Purbasari, Wardah, dan lain-lain. Pemain produk luar negeri yang juga ikut berkiprah yaitu produk kosmetik Maybelline, L'Oreal, NYX dan lain-lain yang ada di Indonesia.(Patmawati \& Syarif, 2020)

Tabel 1. Merek Kosmetik Lokal Paling Populer

\begin{tabular}{cc}
\hline No & Merek Kosmetik \\
\hline 1 & Wardah \\
\hline 2 & Viva Cosmetics \\
\hline 3 & Emina \\
\hline 4 & Martha Tilaar Group \\
\hline 5 & Purbasari \\
\hline
\end{tabular}

Sumber : Katadata, 2020 (Data diolah)

Berdasarkan tabel diatas di analisis oleh katadata.co.id terdapat lima merek kosmetik yang paling populer adalah Wardah, Viva Cosmetics, Emina, Martha Tilaar Group dan Purbasari. Anehnya, Emina yang masih terbilang baru pada Industri pada kosmetik lokal ini menempati peringkat lima besar. Merek kosmetik lokal yang paling populer menempati urutan pertama yaitu Wardah, menduduki urutan kedua yaitu Viva Cosmetics, Urutan ketiga urutan keempat yaitu Martha Tilaar Group dan menempati urutan kelima yaitu Perbasari.

Emina cosmetics merupakan bagian dalam PT. Paragon Tecnology dan Innovation yang berdiri sejak tahun 2015. Emina yang masih tergolong baru dalam industry kosmetik lokal berhasil menduduki peringkat 5 besar, hal ini sangat membuktikan bahwa para remaja memiliki ketertarikan terhadap produk emina. Menurut compass 2021, data penjualan Emina pada Shopee dan Tokopedia, penjualan merek Emina sejak tanggal 1 hingga 18 Februari 2021 telah mencapai 4,5 miliar. Selama periode ini, total volume transaksi yang tercatat telah melebihi 183 ribu.

Kepuasan pelanggan merupakan suatu kunci untuk mencapai kesuksesan suatu perusahaan. Kepuasan pelanggan sudah menjadi konsep sentral didalamnya terdapat teori dan praktik pemasaran, selain salah satu tujuan yang mendasar kegiatan bisnis tersebut. Kepuasan pelanggan pada perusahaan tidak terlepas dari 
harga dan kualitas produk yang telah dilakukan oleh perusahaan.Selain harga tinggi, di mata pelanggan citra merek yang tidak sesuai dengan kualitas produk yang kurang baik dapat menimbulkan ketidakpuasan di kalangan pelanggan.

Terdapat penelitian pendukung yang dilakukan oleh (Patmawati \& Syarif, 2020) menyatakan bahwa "Harga, citra merek dan kualitas produk berpengaruh positif signifikan terhadap Kepuasan Konsumen". Penelitian ini dilakukan (Maharani, Oktavia R, 2020) yang menyatakan bahwa "citra merek dan kualitas produk berpengaruh signifikan terhadap kepuasan pelanggan". Hal berbeda dinyatakan oleh (Setyo, 2017) bahwa "harga tidak berpengaruh secara parsial terhadap kepuasan pelanggan“. Penelitian oleh (Derang, 2017) menyatakan bahwa "citra merek tidak berpengaruh terhadap kepuasan pelanggan". Penelitian oleh (Aulia, 2020) menyatakan bahwa "kualitas produk tidak berpengaruh signifikan terhadap kepuasan pelanggan".

Berdasarkan uraian diatas, maka peneliti tertarik melakukan penelitian untuk mengetahui seberapa besar pengaruh harga, citra merek dan kualitas produk terhadap kepuasan pelanggan pada produk kosmetik Emina. Maka dari hal itu, peneliti mengambil judul "ANALISIS KEPUASAN PELANGGAN PRODUK KOSMETIK EMINA".

\section{METODE}

Penelitian ini menggunakan 100 responden dengan rumus lemeshow melalui kuesioner dengan kriteria: 1) Berdomisili di wilayah Kecamatan Bogor Barat. 2) Pengguna produk kosmetik Emina. 3) Wanita usia minimal 15 Tahun. Jenis data yang digunakan adalah data primer yang diperoleh dari hasil kueisoner melalui google form. Skala yang digunakan untuk mengukur indikator yaitu skala likert 1 sampai 5. Pengolahan data menggunakan software SmartPLS 3.0. Dengan melakukan Uji Validitas dan Uji Realibilitas, kemudian dilakukan Analisis Data Deskriptif dan Inferensial dan melakukan Uji Hipotesis.

\section{HASIL DAN PEMBAHASAN \\ Deskripsi Data Responden}

Dalam penelitian karakteristik responden yang dihasilkan dari penyebaran kuesioner melalui google form di wilayah Kecamatan Bogor Barat yang terbagi berdasarkan usia responden, jenis pekerjaan, dan wilayah kelurahan.

Tabel 8. Karakteristik Responden Berdasarkan Usia

\begin{tabular}{lcc}
\hline Usia & Frekuensi & Persentase \\
\hline $15-20$ Tahun & 10 & $10 \%$ \\
\hline $21-25$ Tahun & 89 & $89 \%$ \\
\hline$>25$ Tahun & 1 & $1 \%$ \\
\hline Jumlah & 100 & $100 \%$ \\
\hline
\end{tabular}

Sumber: Google Form (Data diolah)

Berdasarkan data di atas, jumlah responden dibagi menjadi tiga kategori berdasarkan usia, yaitu 10 responden (10\%) berusia 15-20 tahun, 89 responden (89\%) berusia 21-25, dan 1 orang $>25$ tahun. (1\%). Oleh karena itu, dapat disimpulkan bahwa hasil wawancara pada kecamatan Bogor Barat sebagian besar adalah orang-orang yang berusia 21-25 tahun. Hal ini dikarenakan penyebaran kuesioner ini melalui jejaring sosial seperti WhatsApp, Line dan Instagram.

Tabel 9. Karakteristik Responden Berdasarkan Jenis Pekerjaann

\begin{tabular}{lcc}
\hline Jenis Pekerjaan & Frekuensi & Persentase \\
\hline Pelajar/Mahasiswa & 59 & $59 \%$ \\
\hline Pegawai Swasta & 26 & $26 \%$ \\
\hline PNS & 0 & $0 \%$ \\
\hline Wiraswasta & 3 & $3 \%$ \\
\hline Lainnya & 12 & $12 \%$ \\
\hline Jumlah & 100 & $100 \%$ \\
\hline
\end{tabular}

Sumber: Google Form (Data diolah)

Pada data di atas menunjukkan bahwa jumlah responden berdasarkan jenis pekerjaan terbagi dalam 5 kategori, yaitu responden dengan jenis pekerjaan Pelajar/Mahasiswa berjumlah 59 orang (59\%), responden sebagai Pegawai Swasta sebanyak 26 orang (26\%), responden dengan jenis pekerjaan Pegawai Negeri Sipil 
dalam penelitian ini tidak ada, responden pada jenis pekerjaan Wiraswasta dengan jumlah 3 orang (3\%), dan jenis pekerjaan lainnya sebanyak 12 orang (12\%). Maka dapat disimpulkan bahwa responden pada Kecamatan Bogor Barat ini didominasi jenis pekerjaan sebagai Pelajar /Mahasiswa. Hal tersebut sejalan dengan hasil karakteristik data responden berdasarkan usia, yang mana pada hasil berdasarkan usia yang didapat merupakan usia seorang Pelajar /Mahasiswa.

Tabel 10. Karakteristik Responden Berdasarkan Lokasi

\begin{tabular}{lcc}
\hline Kelurahan & Frekuensi & Persentase \\
\hline Balumbang Jaya & 6 & $6 \%$ \\
\hline Bubulak & 7 & $7 \%$ \\
\hline Cilendek Barat & 7 & $7 \%$ \\
\hline Cilendek Timur & 7 & $7 \%$ \\
\hline Curug & 5 & $5 \%$ \\
\hline Curug Mekar & 5 & $5 \%$ \\
\hline Gunung Batu & 9 & $9 \%$ \\
\hline Loji & 7 & $7 \%$ \\
\hline Margajaya & 9 & $9 \%$ \\
\hline Menteng & 6 & $6 \%$ \\
\hline Pasir Jaya & 4 & $4 \%$ \\
\hline Pasir Kuda & 7 & $7 \%$ \\
\hline Pasir Mulya & 4 & $4 \%$ \\
\hline Semplak & 4 & $4 \%$ \\
\hline Sindang Barang & 8 & $8 \%$ \\
\hline Situ Gede & 5 & $100 \%$ \\
\hline Jumlah & 700 & \\
\hline
\end{tabular}

Sumber: Google Form (Data diolah)

Pada data tersebut menunjukkan lokasi yang berada di wilayah Kecamatan Bogor Barat terbagi menjadi 16 kelurahan, sampel ini diambil secara acak namun mewakili populasi dari masingmasing kelurahan. Sehingga pada wilayah Balumbang Jaya terdapat 6 responden (6\%), wilayah Bubulak terdapat 7 responden (7\%), wilayah Cilendek Barat terdapat 7 responden (7\%), wilayah Cilendek Timur terdapat 7 responden (7\%), wilayah Curug terdapat 5 responden (5\%), wilayah Curug Mekar terdapat 5 responden (5\%), wilayah Gunung Batu terdapat 9 responden (9\%), wilayah Loji terdapat 7 responden (7\%), wilayah Marga Jaya terdapat 9 responden (9\%), wilayah Menteng sebanyak 6 responden (6\%), wilayah Pasir Jaya terdapat 4 responden (4\%), wilayah Pasir Kuda terdapat 7 responden (7\%), wilayah Pasir Mulya terdapat 4 responden (4\%), wilayah Semplak terdapat 4 responden (4\%), wilayah Sindang Barang terdapat 8 responden (8\%) dan wilayah Setu Gede terdapat 5 responden (5\%).

\section{Analisis Data Deskriptif}

Pada penelitian ini teknik analisis data yang digunakan yaitu analisis deskriptif. Menurut (Sugiyono, 2013, hlm. 147) Statistik deskriptif adalah statistik yang digunakan untuk menganalisis data dengan cara mendeskripsikan atau mendeskripsikan data yang dikumpulkan, dan tidak dimaksudkan untuk membuat kesimpulan atau generalisasi secara umum.

1. Analisis Tingkat Respon Responden Terhadap Variabel Kepuasan Pelanggan

Dalam penelitian ini variabel kepuasan pelanggan diukur dengan 6 pertanyaan. Adapun jawaban dan hasil analisis indeks skor tanggapan variabel kepuasan pelanggan adalah sebagai berikut:

Tabel 11. Hasil Tanggapan Responden Terhadap Variabel Kepuasan Pelanggan

\begin{tabular}{lcccccc}
\hline \multirow{2}{*}{$\begin{array}{l}\text { Kepuasan } \\
\text { Pelanggan }\end{array}$} & $\mathbf{1}$ & $\mathbf{2}$ & $\mathbf{3}$ & $\mathbf{4}$ & $\mathbf{5}$ & Indeks \\
\cline { 2 - 6 } Kp1 & 0 & 0 & 9 & 59 & 32 & 84,6 \\
\hline KP2 & 0 & 0 & 3 & 53 & 44 & 88,2 \\
\hline KP3 & 0 & 1 & 13 & 49 & 37 & 84,4 \\
\hline KP4 & 0 & 2 & 19 & 50 & 29 & 81,2 \\
\hline KP5 & 0 & 0 & 16 & 55 & 29 & 82,6 \\
\hline Kp6 & 0 & 0 & 8 & 59 & 33 & 85 \\
\hline & & & Rata - Rata Indeks & 84,3 \\
\hline
\end{tabular}

Source: Processed Data, 2021

Berdasarkan pada tabel di atas, jumlah tertinggi pada butir KP2 dengan indeks 88,2. Adapun nilai indeks 88,2 menurut three box method termasuk kategori tinggi. Dalam butir KP2 memuat pernyataan mengenai kesesuaian produk yang diterima sesuai dengan pesanan. Artinya, responden memiliki persepsi bahwa kesesuaian produk kosmetik Emina yang diterima sesuai dengan yang dipesan. Sedangkan nilai terendah terdapat pada butir KP4 sebesar 81,2 menurut three box method termasuk kategori tinggi. 
Dalam butir KP4 memuat pernyataan mengenai keinginan untuk kembali mengunjungi store Emina. Artinya, responden memiliki persepsi keinginan untuk mengunjungi kembali store Emina. Pada keseluruhan rata-rata nilai indeks jawaban dari variabel kepuasan pelanggan memiliki hasil dengan nilai 84,3 yang mana nilai indeks yang diperoleh menurut three box method termasuk kategori tinggi. Hal tersebut mengindikasikan responden yakni orang yang pernah membeli atau sedang menggunakan produk Kosmetik Emina pada Kecamatan Bogor Barat Kota Bogor merasakan kepuasan pelanggan terhadap produk kosmetik Emina.

2. Analisis Indeks Jawaban Responden Terhadap Variabel Harga

Dalam variabel harga pada penelitian ini diukur dengan menggunakan 8 butir pertanyaan. Hasil jawaban dan analisis indeks skor jawaban terhadap variabel harga disajikan dalam tabel sebagai berikut:

Tabel 12. Hasil Tanggapan Responden Terhadap Variabel Harga

\begin{tabular}{lcccccc}
\hline \multirow{2}{*}{ Harga } & \multicolumn{5}{c}{ Frekuensi } & Indeks \\
\cline { 2 - 6 } & $\mathbf{1}$ & $\mathbf{2}$ & $\mathbf{3}$ & $\mathbf{4}$ & $\mathbf{5}$ & \\
\hline H1 & 0 & 1 & 4 & 42 & 53 & 89,7 \\
\hline H2 & 0 & 2 & 4 & 49 & 45 & 78,4 \\
\hline H3 & 0 & 0 & 6 & 55 & 39 & 86,6 \\
\hline H4 & 0 & 0 & 14 & 54 & 32 & 83,6 \\
\hline H6 & 0 & 0 & 5 & 57 & 38 & 86,6 \\
\hline H7 & 0 & 2 & 15 & 37 & 46 & 85,4 \\
\hline H8 & 0 & 0 & 19 & 51 & 30 & 82,2 \\
\hline & & & Rata - Rata Indeks & 84,5 \\
\hline
\end{tabular}

Sumber: Data diolah

Pada tabel diatas yang memiliki nilai indeks tertinggi pada butir H1 yaitu 89,7. Nilai yang diperoleh butir $\mathrm{H} 1$ menurut three box method termasuk kedalam kategori tinggi. Dalam butir tersebut memuat pernyataan mengenai harga produk kosmetik Emina yang terjangkau. Artinya responden memiliki persepsi bahwa harga yang dimiliki Emina termasuk kedalam harga yang terjangkau. Selanjutnya, nilai indeks terendah pada variabel produk ini terdapat pada butir $\mathrm{H} 2$ dengan nilai 78,4, menurut three box method termasuk kedalam kategori tinggi. Dalam butir tersebut memuat pernyataan mengenai variasi harga sesuai dengan produk kosmetik Emina. Artinya dalam butir pernyataan tersebut responden memiliki persepsi bahwa variasi harga diberikan ini sesuai dengan produk yang diterima.

Selanjutnya, rata-rata nilai indeks skor jawaban pada harga yakni 84,5 , emenurut three box method termasuk kedalam kategori tinggi. Yang artinya hal tersebut mengindikasikan bahwa responden yakni orang yang pernah membeli atau sedang menggunakan kosmetik Emina setuju jika Harga yang diberikan oleh Emina sesuai dengan yang dirasakan.

3. Analisis Tingkat Tanggapan Responden Terhadap Variabel Citra Merek

Dalam penelitian ini pengukuran variabel citra merek menggunakan 6 pertanyaan. Hasil tanggapan dan analisis indeks skor tanggapan untuk variabel citra merek adalah sebagai berikut:

Tabel 13. Hasil Tanggapan Responden Terhadap Variabel Citra Merek

\begin{tabular}{lcccccc}
\hline \multirow{2}{*}{ Citra Merek } & \multicolumn{5}{c}{ Frekuensi } & Indeks \\
\cline { 2 - 6 } & $\mathbf{1}$ & $\mathbf{2}$ & $\mathbf{3}$ & $\mathbf{4}$ & $\mathbf{5}$ & \\
\hline Cm1 & 0 & 0 & 8 & 61 & 31 & 84,6 \\
\hline CM2 & 0 & 0 & 8 & 51 & 41 & 86,6 \\
\hline CM3 & 0 & 0 & 4 & 53 & 43 & 87,8 \\
\hline CM4 & 0 & 0 & 9 & 46 & 35 & 77,2 \\
\hline CM5 & 0 & 0 & 4 & 49 & 47 & 88,6 \\
\hline Cm6 & 0 & 0 & 9 & 51 & 40 & 86,2 \\
\hline & & & Rata - Rata Indeks & 85,1 \\
\hline
\end{tabular}

Sumber: Data diolah

Pada nilai indeks jumlah tertinggi CM yaitu 88,6, nilai yang diperoleh butir CM5 menurut three box method termasuk kategori tinggi. Dalam butir tersebut memuat pernyataan mengenai kemasan produk Emina yang menarik. Artinya responden memiliki persepsi bahwa merek kosmetik Emina merupakan merek yang memiliki kemasan yang menarik sebagai daya tarik produk tersebut. Selanjutnya, nilai indeks terendah pada variabel produk ini terdapat pada 
butir CM4 dengan nilai 77,2. Dengan nilai ini menurut three box method termasuk kategori tinggi. Dalam butir tersebut memuat pernyataan mengenai produk kosmetik Emina memiliki kemasan yang menarik. Artinya dalam butir pernyataan tersebut responden memiliki persepsi bahwa Emina merupakan kosmetik yang mudah diingat oleh pelanggan.

Selanjutnya, rata-rata pada indeks jumlah jawaban variabel citra merek yakni 85,1. Nilai ini menurut three box method termasuk kategori tinggi. Yang artinya hal tersebut mengindikasikan bahwa responden yakni orang yang pernah membeli atau sedang menggunakan produk kosmetik Emina setuju jika Emina merupakan merek yang memiliki kemasan yang menarik dan Emina merupakan produk kosmetik yang umum diketahui dan diingat oleh pelanggan.

4. Analisis Tingkat Tanggapan Responden Terhadap Variabel Kualitas Produk

Dalam variabel kualitas produk penelitian ini, 8 pertanyaan digunakan untuk mengukur. Hasil analisis variabel respon terhadap kualitas produk dan indeks penilaian respon ditunjukkan pada tabel berikut:

Tabel 14. Hasil Tanggapan Responden Terhadap Variabel Kualitas Produk

\begin{tabular}{lcccccc}
\hline \multirow{2}{*}{$\begin{array}{l}\text { Kualitas } \\
\text { Produk }\end{array}$} & $\mathbf{5}$ & $\mathbf{2}$ & $\mathbf{3}$ & $\mathbf{4}$ & $\mathbf{5}$ & Indeks \\
\cline { 2 - 6 } KPK1 & 0 & 0 & 8 & 53 & 39 & 86,2 \\
\hline KPK2 & 0 & 0 & 14 & 57 & 29 & 83 \\
\hline KPK3 & 0 & 5 & 25 & 46 & 24 & 77,8 \\
\hline KPK4 & 0 & 0 & 16 & 56 & 28 & 82,4 \\
\hline KPK5 & 0 & 0 & 14 & 59 & 27 & 82,6 \\
\hline KPK6 & 0 & 0 & 15 & 60 & 25 & 82 \\
\hline KPK7 & 0 & 0 & 3 & 53 & 44 & 88,2 \\
\hline KPK8 & 0 & 1 & 7 & 56 & 36 & 85,4 \\
\hline & \multicolumn{7}{c}{ Rata - Rata Indeks } & 83,4 \\
\hline
\end{tabular}

Sumber: Data diolah

Pada tabel diatas nilai tertinggi pada KPK7 yaitu 88,2. Nilai yang diperoleh butir KPK7 menurut three box method termasuk kategori tinggi. Dalam butir tersebut memuat pernyataan mengenai produk kosmetik Emina memiliki berbagai jenis produk kosmetik. Artinya responden memiliki persepsi bahwa kosmetik Emina memiliki berbagai jenis produk kosmetik. Selanjutnya, nilai indeks terendah pada variabel produk ini terdapat pada butir KPK3 dengan nilai 77,8. Dengan nilai menurut three box method termasuk kategori tinggi. Dalam butir tersebut memuat pernyataan mengenai produk kosmetik Emina memiliki daya tahan lama saat diaplikan pada wajah. Artinya responden memiliki persepsi bahwa Emina memiliki daya tahan yang lama saat di aplikasikan pada wajah.

Selanjutnya, nilai rata-rata pada indeks jumlah jawaban kualitas produk yakni 83,4. Nilai menurut three box method termasuk kategori tinggi. Yang artinya hal tersebut mengindikasikan bahwa responden yakni orang yang pernah membeli atau sedang menggunakan produk kosmetik Emina setuju jika Emina memiliki berbagai jenis produk kosmetik yang mudah digunakan pada wajah.

\section{Uji Validitas Konvergen}

Hasil output SmartPLS 3.0 diperoleh loading faktor masing-masing pada indikator alat dan variabel kepuasan pelanggan, harga, citra merek dan kualitas produk sebagai berikut:

Tabel 15. Hasil Nilai Outer Loading Factor

\begin{tabular}{|c|c|c|c|c|}
\hline & $\begin{array}{l}\text { Kepuasan } \\
\text { Pelanggan }\end{array}$ & Harga & $\begin{array}{c}\text { Citra } \\
\text { Merek }\end{array}$ & $\begin{array}{c}\text { Kualitas } \\
\text { Produk }\end{array}$ \\
\hline Kp1 & 0,857 & & & \\
\hline KP2 & 0,719 & & & \\
\hline KP3 & 0,809 & & & \\
\hline KP4 & 0,782 & & & \\
\hline KP5 & 0,852 & & & \\
\hline KP6 & 0,784 & & & \\
\hline H1 & & 0,659 & & \\
\hline H2 & & 0,733 & & \\
\hline H3 & & 0,805 & & \\
\hline H4 & & 0,851 & & \\
\hline H5 & & 0,755 & & \\
\hline H6 & & 0,633 & & \\
\hline H7 & & 0,862 & & \\
\hline H8 & & 0,751 & & \\
\hline CM1 & & & 0,759 & \\
\hline
\end{tabular}




\begin{tabular}{lll}
\hline CM2 & 0,832 & \\
\hline CM3 & 0,695 & \\
\hline CM4 & 0,733 & \\
\hline CM5 & 0,795 & \\
\hline KPK1 & 0,830 & \\
\hline KPK2 & & 0,734 \\
\hline KPK3 & 0,862 \\
\hline KPK4 & 0,780 \\
\hline KPK5 & 0,695 \\
\hline KPK6 & & 0,872 \\
\hline KPK7 & 0,792 \\
\hline KPK8 & & 0,748 \\
\hline
\end{tabular}

uji realibilitas tersebut bisa dilihat pada hasil output SmartPLS 3.0 pada nilai Cronbach's Alpha dan Composite Realibility pada tiap variabel konstruk sebagai berikut:

Tabel 17. Hasil Nilai Cronbach Alpha dan Composite Reliability

\begin{tabular}{lcc}
\hline & $\begin{array}{c}\text { Cronbach's } \\
\text { Alpha }\end{array}$ & $\begin{array}{c}\text { Composite } \\
\text { Reliability }\end{array}$ \\
\hline Kepuasan Pelanggan & 0,888 & 0,915 \\
\hline Harga & 0,894 & 0,915 \\
\hline Citra Merek & 0,868 & 0,900 \\
\hline Kualitas Produk & 0,911 & 0,929 \\
\hline
\end{tabular}

Sumber: Hasil Output SmartPLS 3.0

Sumber: Hasil Output SmartPLS 3.0

Tabel diatas menunjukkan bahwa nilai diatas 0,5 yang artinya bahwa setiap indikator dinyatakan valid dan memenuhi.

\section{Uji Validitas Diskriminan}

Dalam penguijan validitas diskriminan ini pula didapatkan hasil dari SmartPLS 3.0 yaitu nilai Average Variance Extracted (AVE) pada setiap masing variabel Kepuasan pelanggan, harga, citra merek dan kualitas produk. Berikut hasil output pada PLS 3.0 mengenai Average Variance Extracted (AVE):

Tabel 16. Average Variance Extracted (AVE)

\begin{tabular}{lc}
\hline & Average Variance Extracted (AVE) \\
\hline Kepuasan Pelanggan & 0,643 \\
\hline Harga & 0,578 \\
\hline Citra Merek & 0,602 \\
\hline Kualitas Produk & 0,620 \\
\hline
\end{tabular}

Sumber: Hasil Output SmartPLS 3.0

Berdasarkan hasil diatas bahwa nilai AVE tersebut lebih besar dari 0,50 untuk seluruh variabel. Sehingga dapat diartikan bahwa alat yang diukur dapat mengukur apa yang akan diukur secara konsisten yaitu kepuasan pelanggan, harga, citra merek dan kualitas produk.

\section{Uji Realibilitas}

Setelah diperolehnya validitas pada tiap instrumen pertanyaan setiap variabel, maka langkah selanjutnya yakni uji realibilitas. Dalam

Hasil dari realibilitas nilai output cronbach's alpha dan composite realibility secara menyeluruh berada pada kategori yang tinggi karena nilai $>0,7$, hal ini dapat diartikan bahwa terdapat konsistensi alat ukur yang digunakan sangat baik dan dapat digunakan untuk kasus yang sama dimanapun serta butir pernyataan pada kuesioner ini bersifat relevan.

\section{Uji R-Square}

Hasil pada output SmartPLS 3.0 terkait uji R square yaitu sebagian berikut:

Tabel 18. Nilai Adjusted R Square

\begin{tabular}{lc}
\hline & Adjusted R Square \\
\hline Kepuasan Pelanggan (Y) & 0,759 \\
\hline
\end{tabular}

Sumber:;Hasil Output SmartPLS 3.0

Pada tabel ini, dapat dilihat bahwa besar nilai adjusted R Square Kepuasan Pelanggan yaitu 0,759 tersebut menunjukan adanya kontribusi pada variabel harga, citra merek dan kualitas produk terhadap kepuasan pelanggan yaitu sebesar 0,759 atau 75,9\% dan sisanya sebesar $24,1 \%$ kontribusi pada kepuasan pelanggan dari variabel lain yang telah diteliti pada peneliti yaitu persepsi kualitas, citra perusahaan, dan lainlain.

\section{Uji Hipotesis}

Berdasarkan pengelolaan data struktur dari analisis koefisien jalur SmartPLS 3.0, hasilnya sebagai berikut: 
Tabel 19. Hasil Nilai Koefisien Analisis Jalur

\begin{tabular}{lccc}
\hline & Original Sampel (0) & Sampel Mean (M) & Standart Deviation (STDEV) \\
\hline Harga (X1) $\Rightarrow$ Kepuasan Pelanggan & 0,323 & 0,331 & 0,115 \\
\hline Citra Merek (X2) $\Rightarrow$ Kepuasan Pelanggan & 0,173 & 0,173 & 0,085 \\
\hline Kualitas Produk (X3) $\Rightarrow$ Kepuasan Pelanggan & 0,457 & 0,451 & 0,112 \\
\hline
\end{tabular}

Sumber: Hasil Output SmartPLS 3.0

Pada tabel diatas, bisa dilihat bahwa tabel sampel asli (0) yang menjelaskan nilai dari koefisien analisis jalur. Pada hasil perhitungan diatas dapat dilihat pula pada variabel harga terhadap keunggulan bersaing memiliki nilai sampel asli sebesar 0,323, maka dapat diartikan bahwa besarnya kontribusi harga terhadap kepuasan pelanggan yaitu sebesar $32,3 \%$, lalu pada variabel citra merek terhadap kepuasan pelanggan memiliki nilai sampel asli sebesar 0,173 maka dapat diartikan bahwa besarnya kontribusi citra merek terhadap kepuasan pelanggan yaitu sebesar $17,3 \%$. Dan pada hasil perhitungan variabel kualitas produk terhadap kepuasan pelanggan mendapatkan nilai sampel asli sebesar 0,457 maka bisa diartikan besarnya kontribusi kualitas produk terhadap kepuasan pelanggan yaitu sebesar $45,7 \%$.

\section{Pembahasan}

1. Pengaruh Harga Terhadap Kepuasan Pelanggan

Harga berpengaruh dan signifikan terhadap kepuasan pelanggan, hal ini berdasarkann pengolahan pada data uji $t$ statistic menunjukan pada variabel harga adanya kepuasan pelanggan yang artinya adalah harga berpengaruh terhadap kepuasan pelanggan. Artinya dalam variabel harga dengan indikator yang digunakan yaitu keterjangkauan harga, kesesuaian harga dengan kualitas, daya saing dan kesesuaian harga dengan manfaat dianggap telah berkontribusi dalam mempengaruhi variabel kepuasan pelanggan. Dalam menetapkan harga yang ditawarkan oleh produk kosmetik Emina sangat terjangkau tentunya memiliki harga yang sangat terjangkau dibanding pesaing serta harga kosmetik Emina sesuai dengan kualitas yang didapatkan. Dengan memiliki harga yang terjangkau dibanding pesaing dan harga sesuai dengan kualitas yang diharapkan dapat menimbulkan adanya kepuasan pelanggan karena produk kosmetik Emina.

2. Pengaruh Citra Merek Terhadap Kepuasan Pelanggan

Citra merek berpengaruh dan signifikan terhadap kepuasan pelanggan, hal tersebut didasarkan atas pengolahan data uji t statistik menunjukan citra merek berpengaruh terhadap kepuasan pelanggan. Besar pengaruh citra merek terhadap kepuasan pelanggan dalam variabel citra merek dengan indikator merek dipercaya, merek dikenal dan pembeda merek dianggap berkontribusi dalam mempengaruhi variabel kepuasan pelanggan. Merek Emina dikenal sebagai produk yang memiliki bahan yang sangat ringan untuk wajah. Sehingga hal tersebut menjadikan adanya kepuasan pelanggan produk kosmetik Emina.

3. Pengaruh Kualitas Produk Terhadap Kepuasan Pelanggan

Kualitas produk berpengaruh dan signifikan terhadap kepuasan pelanggan, hal tersebut didasarkan atas hasil pengolahan data uji $\mathrm{t}$ statistik menunjukan kualitas produk berpengaruh terhadap kepuasan pelanggan. Besar pengaruh kualitas produk terhadap kepuasan pelanggan dalam variabel kualitas produk yang menggunakan indikator kemudahan penggunaan, daya tahan, manfaat produk dan keragaman produk dianggap telah berkontribusi dalam mempengaruhi variabel kepuasan pelanggan. Produk kosmetik Emina memiliki berbagai jenis kosmetik yang cukup lengkap dengan 
komposisi bahan yang ringan tentunya dengan kualitas yang memiliki daya tahan lama saat digunakan pada wajah.

\section{KESIMPULAN DAN SARAN Kesimpulan}

Berdasarkan hasil analisis dan pembahasan yang telah dijelaskan pada bab sebelumnya melalui Partial Least Square atau PLS mengenai analisis kepuasan pelanggan terhadap produk kosmetik Emina dan pengujian yang telah dilakukan maka dapat disimpulkan bahwa harga mempengaruhi kepuasan pelanggan bagi Emina produk kosmetik yaitu harga yang ditawarkan produk kosmetik Emina sudah cukup memberikan kontribusi terhadap kepuasan pelanggan dengan menawarkan harga yang terjangkau dibandingkan kompetitor lainnya. Oleh karena itu, hal ini sesuai dengan asumsi yang dibuat oleh peneliti, khususnya harga mempengaruhi kepuasan pelanggan kosmetik Emina. Citra merek memiliki pengaruh terhadap kepuasan pelanggan terhadap produk kosmetik Emina, artinya citra merek yang dimiliki oleh perusahaan Emina menganggap sebuah merek Emina dikenal sebagai produk yang mengandung bahan-bahan yang sangat ringan di wajah. Emina Cosmetics telah melakukan cukup banyak untuk meningkatkan kepuasan pelanggan. Oleh karena itu, sesuai dengan asumsi yang telah dibuat yaitu citra merek mempengaruhi kepuasan pelanggan terhadap produk kosmetik Emina. Kualitas produk berpengaruh terhadap kepuasan pelanggan terhadap kosmetik Emina, artinya kualitas produk yang dimiliki Emina memberikan efek wajah yang optimal dan sudah cukup berkontribusi terhadap peningkatan kepuasan pelanggan. Oleh karena itu sesuai dengan asumsi yang telah dibuat yaitu kualitas produk berpengaruh terhadap kepuasan pelanggan terhadap produk kosmetik Emina.

\section{Saran}

Berdasarkan hasil analisis dan pembahasan serta manfaat penelitian ini, maka penulis dapat memberikan rekomendasi sebagai berikut:

1. Pada variabel harga, hasil dalam penelitian ini maka peneliti menyarankan kepada perusahaan kosmetik Emina harus menyesuaikan harga produk yang ditawarkan dengan kualitas yang dihasilkan dan manfaat yang dirasakan pada produk serta memiliki harga yang lebih terjangkau sehingga pelanggan akan memilih produk kosmetik Emina. Maka dari itu, perusahaan harus tetap mempertahankan harga yang terjangkau untuk meningkatkan kepuasan pelanggan.

2. Pada variabel citra merek, hasil dari penelitian ini maka peneliti menyarankan kepada perusahaan kosmetik Emina bahwa citra merek tersebut harus memiliki pengaruh terhadap kepuasan pelanggan. Perusahaan perlu terus mempertahankan dan meningkatkan citra merek Emina sebagai produk yang diingat dibenak pelanggan yang memiliki bahan yang ringan untuk wajah. Sehingga saat pelanggan ingin membeli produk kosmetik, maka yang pertama kali diingat adalah merek Emina.

3. Pada variabel kualitas produk, hasil dari penelitian ini maka peneliti menyarankan kepada perusahaan kosmetik Emina bahwa kualitas produk harus memiliki pengaruh terhadap kepuasan pelanggan. Perusahaan perlu mempertahankan kualitas produk yang memberikan hasil optimal bagi wajah. Sehingga pelanggan akan merasa puas dan dapat meningkatkan kepuasan pelanggan.

\section{R E F E R E N C E}

\section{Book}

Alkautsar, A. J., Mardiatmi, B. D., \& Rosali. (2019). Kualitas Produk, Kualitas Layanan, Kepuasan Konsumen pada KFC Jatiasih Kota Bekasi. 126(1), 1-7. 
Astuti, M., \& Matondang, N. (2020). Manajemen Pemasaran: UMKM dan Digital Sosial Media. Sleman: 978-623-02-2065-4.

\section{Book with Editor}

Abdullah, T., \& Francis Tantri. (2019). Manajemen Pemasaran (1st ed.). Depok: Rajawali Pers

Firmansyah, M, A. (2018). Perilaku Konsumen (sikap dan pemasaran). Deepublish. Retrieved from www.freepik.com

Firmansyah, M, A. (2019). Pemasaran Produk dan Merek: Planning dan strategy. Qiara Media.

Gozhali, I. (2014). Aplikasi Analisis Multivariate Dengan Program SPSS. Semarang: Badan Penerbit UNDIP.

Gozhali, I. (2018). Aplikasi Analisis Multivariate Dengan Program IBM SPSS 25. Semarang: Badan Penerbit Universitas Diponegoro.

Indrasari, M. (2019). Pemasaran dan Kepuasan Pelanggan. Surabaya: Unitomo Press.

Kotler, P., \& Amstrong, G. (2016). Prinsip-prinsip Pemasaran (12th ed.; A. Maulana, D. Barnadi, \& W. Hardani, Eds.). Erlangga.

Poniman, B., \& Choerudin, A. (2017). Manajemen Pemasaran. Yogyakarta: Deepublish.

Tjiptono, Fandy , Ph.D, A. D. (2017). Pemasaran Stratejik Edisi 3. Yogyakarta: Andi.

\section{Mass Media with Known Author}

Lusiah. (2018). Loyalitas Pelanggan Berdasarkan Hasil Penelitian Pada Mahasiswa Universitas Swasta di Kota Medan. Deepublish.

\section{Journal Article}

Anggraini, F. (2020). Fifin Anggraini Anindhyta Budiarti Abstrak Pengaruh Harga ,Promosi ,Dan Kualitas Pelayanan Terhadap Loyalitas .... 08, 86-94.

Fitriani, J., Sumaryono, W., \& Derriawan. (2019). Pengaruh Kualitas Produk dan Perawatan Terhadap Kepuasan dan Loyalitas Pasien Klinik Kecantikan Pertama Kota Bekasi. 3(3), 246-255.

Maharani, Oktavia R, H. W. dan T. H. A. (2020). Pengaruh Citra Merek dan Kualitas Produk pada Kepuasan Konsumen Dimoderasi oleh Loyalitas (Study Kasus pada Lipstcik Wardah). 4.

Patmawati, N. S., \& Syarif, R. (2020). Pengaruh Harga , Citra Merek Dan Kualitas Produk Terhadap Kepuasan Konsumen Emina Di Mall Kota Kasablanka Jurnal IKRA-ITH Ekonomika Vol 3 No 3 Bulan November 2020Jurnal IKRA-ITH Ekonomika Vol 3 No 3 Bulan November 2020. 3(47), 73-83.

Santosa, W. S. dan Adji, N. A. (2007) The Investigation of Ground Water Potential by Vertical Electrical Sounding (VES) Approach in Arguni Bay Region, Kaimana Regency, West Papua. Forum Geografi. Vol. 21, No.1, pp. 103-115.

\section{Web (avoid this source when possible)}

antaranews. (2021). Kemenperin: Industri kosmetik tumbuh signifikan pada 2020. Retrieved March 16, 2021, from antaranews.com website: https://www.antaranews.com/berita/2003853/ kemenperin-industri-kosmetik-tumbuh-signifikan-pada-2020

Compas. (2021). Sebagai Salah Satu Brand Favorit Remaja, Penjualan Brand Emina Capai Rp 4,5 Miliar. Retrieved March 19, 2021, from Compas.co.id website: https://compas.co.id/article/datapenjualan-emina/

falmalkes. (2018). Grafik Rekapitulasi Industri Kosmetika di Indonesia. Retrieved March 17, 2021, from farmalkes.kemkes.go.id website: http://farmalkes.kemkes.go.id/2013/02/grafikrekapitulasi-industri-kosmetika/

Katadata. (2020). 50 Merek Lokal Paling Populer. Retrieved April 25, 2021, from Katadata.co.id website: https://katadata.co.id/merek-lokal 2020 